\title{
Decreasing Ice Coverage Will Reduce the Breeding Success of Baltic Grey Seal (Halichoerus grypus) Females
}

\begin{abstract}
Baltic grey seals (Halichoerus grypus) alternate between land and ice breeding, depending on ice conditions. We show that the fitness of grey seal females in terms of pup mortality and quality is reduced when breeding on land as compared with ice. The mean preweaning mortality rate on land was $21.1 \%$ (range $0 \%$ to $31.6 \%$ ), and correlated with birth density (range 0.5-5.2 pups $100 \mathrm{~m}^{-2}$ ). The mean mortality rate on ice was $1.5 \%$, where the highest density was 0.2 pups $100 \mathrm{~m}^{-2}$ in particularly dense breeding groups. Mean weights of pups born on ice were significantly greater $(48.3 \pm 8.1 \mathrm{~kg})$ at the onset of moult as compared with pups born on land $(37.4 \pm 7.8 \mathrm{~kg})$. Because indices of life-time net reproductive rate (pup survival) and pup quality (weaning weight and health) were more auspicious on ice as compared with land, diminishing ice fields will lower the fitness of Baltic grey seal females and substantially increase the risk for quasi-extinction.
\end{abstract}

\section{INTRODUCTION}

Reduction of ice coverage in the Arctic has been predicted to result in a more northern distribution of marine mammals adapted to the habitats provided by ice (1). Such profound ecosystem changes may hamper their possibilities to forage and reproduce (2), but also bring formerly mainly separated species into contact (3). However, the future scenario of more northern distributions of marine mammals (1) adapted to ice is not an option for land-locked species such as Baikal, Caspian, Ladoga, Saimaa, and Baltic seals. All these seals breed mainly or exclusively on ice, and there is currently no data on possible consequences of diminishing ice fields for these land-locked species.

Modeling suggests that the "normal" ice conditions, where near $50 \%$ of the Baltic has been covered by ice during the past 50 years (4), are predicted to develop into a situation where ice fields are restricted to fractions of the most northerly bay (5). For facultative land/ice breeders this would imply a shift from mainly ice breeding to land breeding.

In this study we analyze how the fitness of Baltic grey seal (Halichoerus grypus) females is affected by giving birth on land instead of ice. We define female fitness as numbers of offspring in the far future according to McNamara and Houston (6), which in practice has two major components: life-time net reproductive rate $\left(R_{0}\right)$ measured as numbers of offspring (7) and the quality of offspring (6). We argue that pup survival rate and pup weight at weaning are appropriate indices for $\mathrm{R}_{0}$ and pup quality, respectively, and discuss the implications of our findings with regard to future effects on population growth rates and extinction risk.

\section{MATERIALS AND METHODS}

\section{Study Population}

The Baltic Sea was colonized by grey seals only some 9000 years ago after the last glaciation, and genetic data (8) suggest that the
Baltic grey seals can be treated as an isolated population in most contexts. According to archaeological data and hunting statistics, the grey seal was earlier distributed throughout the entire Baltic, although the highest densities have always been in the central and northern areas ever since the Mesolithic some 8000 years before present (9).

Population surveys in the 1960s indicated the Baltic grey seal to be a typical ice-breeding pinniped, giving birth in FebruaryMarch on the drift ice in the central and northern Baltic (10). Births of pups on land have generally not been documented during the latter half of the 20th century (10), although breeding on land has been reported from several regions in the Baltic Sea before the 1950s (11).

\section{Breeding on Ice}

The location and extent of pack ice show considerable annual variations. During mean ice conditions, drift ice suitable for breeding can be found in the northern part of the Baltic Proper with relatively narrow extensions down to Öland on the Baltic west coast and along the Estonian and Latvian coasts in the east (Fig. 1). During mild winters the ice edge does not reach these areas in the breeding season, and grey seals in the region are confined to breed on land. Historical ice records show that approximately one-third of winters provided insufficient icecover for ice breeding in the southern Baltic (4). Although mild winters appeared randomly throughout the recorded history 1720-2000, a series of mild winters predominated the study period 1990-2001 (4).

Baltic grey seals mainly breed in pack ice formations close to the fast ice edge or on larger ice floes. Seals keep close to natural openings and cracks and are not known to establish systems of breathing- and haulout-holes in the fast ice as found in Baltic ringed seals (Phoca hispida botnica) (10). The drift ice used by grey seals for breeding is mostly in shelter from direct wave action, and the utilized ice floes are thick and large enough to provide a stable substratum for the whole length of the nursing period (10). The samples for this study were taken from the latter habitat type, and because of the severe ice conditions, the field work was carried out from icebreakers equipped with helicopters.

The ice data was collected from the drift-ice in the Baltic Proper and the Bothnian Bay in 1990-1993 (Fig. 1). Sighted pups were caught, measured, and inspected for external pathological changes. Ice breeding was observed to occur in Estonia, and data from 2001 are related to the more extensive sampling in the Central and Northern Baltic.

\section{Land Breeding}

Surveys carried out since 1990 revealed extensive breeding on land in the west Estonian archipelago in the east Baltic (Fig. 1), the Stockholm county (Sweden) in the west Baltic, and the Finnish Southwestern Archipelago (12). One major breeding group was observed at Allirahu (Fig. 1), situated in the northern part of the Gulf of Riga, about $7 \mathrm{~km}$ from the southern coast of 


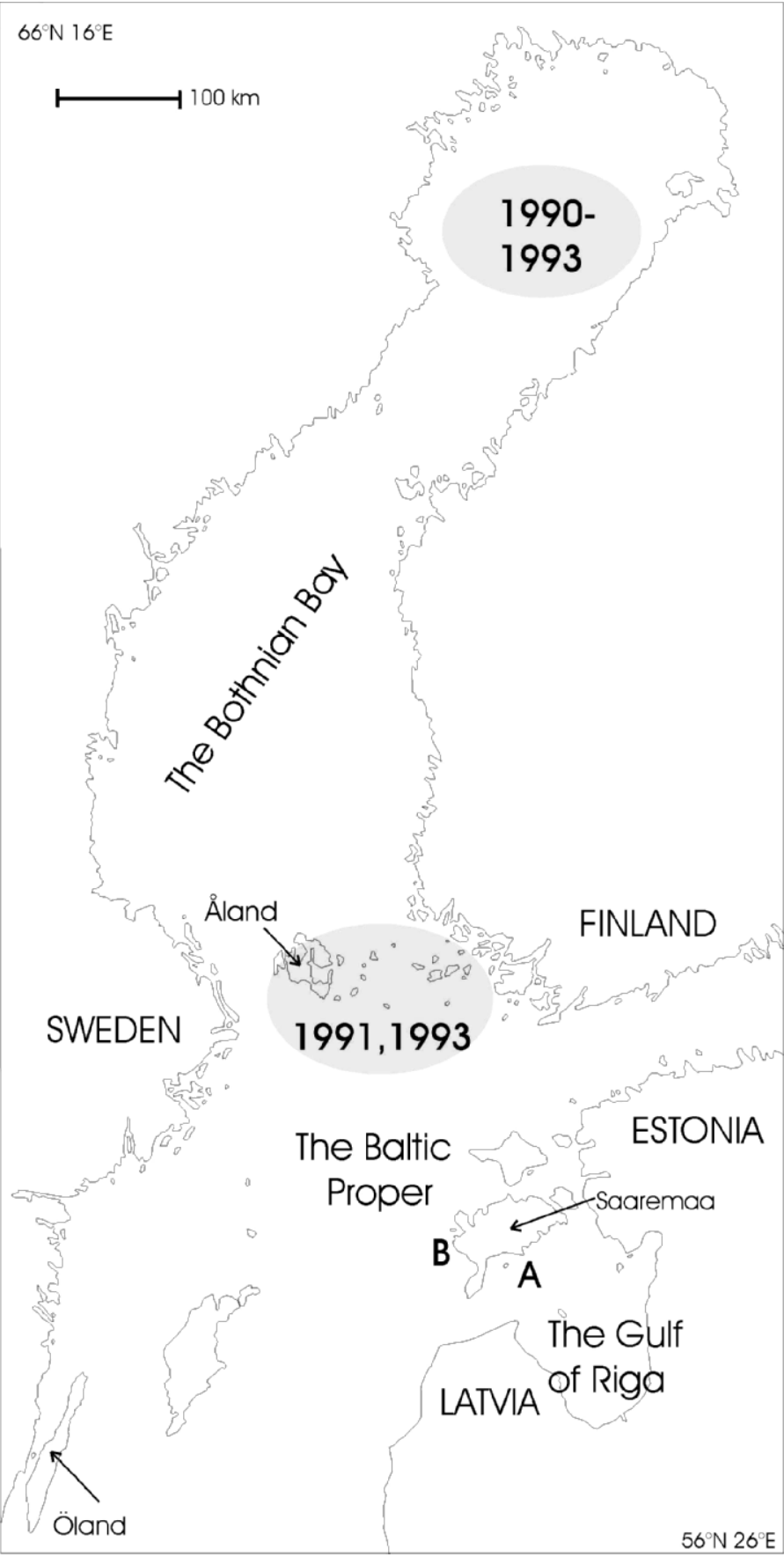

Figure 1. Location of land study sites Allirahu (A), Innarahu (B), and ice areas from where data were collected during ice expeditions. The 2001 ice data were collected from the northern part of the Gulf of Riga (Estonia).

Saaremaa. Here the breeding area consists of several sandy or gravel islets with the maximum elevation at about $1.5 \mathrm{~m}$ above the mean sea level. Shapes and sizes of these islets are modified annually by ice and currents. Although there are no tides in the Baltic Sea, the sea level fluctuates with atmospheric conditions such that the islets can be partially flooded, which makes the area that is available for breeding variable.

A second major breeding group was found at Innarahu (Fig. 1), which is situated at the west coast of Saaremaa, $800 \mathrm{~m}$ from the main island. The maximum elevation of the islet is approximately $3.5 \mathrm{~m}$ above sea level, and the area of the islet is not affected by the sea level, because of the steep shore line consisting of gravel and stones. The area where births took place was restricted to coastal slopes that make up about $75 \%$ of the total area of the islet $\left(8000 \mathrm{~m}^{2}\right)$. The Estonian names of both sites, referring to grey seals or to grey seal reproduction, suggest that land breeding of grey seals has occurred at these islets for centuries.

Data on land breeding were collected at the Estonian coast in 1990-2001 (Fig. 1). The breeding islets were visited using inflatable boats equipped with outboard engines. In 1994 and 1996, land breeding sites were locked in the ice and were not accessible by boat. However, early visits after the break-up of ice cover did not reveal evidence of breeding. In all other years the land breeding sites were visited twice as a minimum, and up to 6 times, to ensure that pups from early and late breeders were sampled.

\section{Numbers of Pups and Pup Mortality}

From the ice habitat, a sample of 414 pups captured in 1990-1993 in the Central and Northern Baltic and 200 additional pups in the northern part of the Gulf of Riga in 2001 provided information on mortality and morbidity rates as well as breeding group size and density. At the breeding islands, pup production was estimated by noninvasive stage structured censuses of total numbers observed. The grey seal neonates go through a sequence of well distinguishable developmental stages, lasting only a couple of days each. Newborn pups (stage 0 ) can be distinguished from older by a combination of features such as presence of blood, birth fluids, and weak response to disturbance. Subsequent age stages $(1,1.5,2.0,2.5$, and 3.0) are determined from other features such as the condition of the umbilicus, body contour, and the intact lanugo fur $(13,14)$. Stage class 3.5 is defined as the onset of moult, which always starts on the head and the flippers, whereas pups in stage class 4 share all characteristics of stage class 3.5 except for that more than $50 \%$ of the lanugo fur is moulted. Stage class 5 denotes fully moulted pups (12). This noninvasive method is widely used as an indication of the developmental stage of an individual pup, and for larger groups of seals it provides the possibility to estimate the phase of breeding season and the total pup production $(10,13$, 14). Pup mortality rates are given as the ratio of recorded numbers of dead pups in relation to total numbers of pups observed on ice and estimated total numbers born on land.

Innarahu was used for analysis of density-dependent effects. Density is given as numbers of births per $100 \mathrm{~m}^{2}$, where the total area available for breeding was $6000 \mathrm{~m}^{2}$. External injuries and pathological changes were noted during 1990-1993 and 1995 in live pups, and a sample of 46 dead pups collected in 1997 were externally examined. From the ice in the Bothnian Bay, 409 live pups were examined for external injuries.

Mother-pup pairs were scattered in the drift ice, and we studied the density of births as group size on the one hand and distance to the nearest neighbor on the other. We measured the distance to closest neighbor $(\mathrm{m})$ and divided the data into seven categories: 0-50, 51-100, 101-200, 201-300, 301-400, 401-500, and $>500 \mathrm{~m}$, where we regard the last category as single mother-pup pairs without association to other seals.

\section{Pup Weaning Mass}

Pups were weighed with a spring scale with an accuracy of \pm 0.5 $\mathrm{kg}$ in 1991-1993 on land breeding sites, and in 1990 and 1991 on ice in the Bothnian Bay and the Baltic proper. We used the mass of pups in stages 3.5 to 4.0 (corresponding to about 16 to 18 days after birth) as indices of weaning mass because weaning occurs in the earliest moulting stages (13). For this analysis we had access to 90 pups from land breeding sites and 89 pups from the ice in the critical stage classes.

We used the mean value for the first stage class pups $(12.1 \mathrm{~kg})$ as the mean birth mass both on ice and at land breeding sites, which is expected to be slightly heavier than the true birth mass. 
Table 1. Weaning weights (Stage classes 3.5 and 4.0 combined, see text) of Baltic grey seal pups from land breeding sites and ice. Weaners on ice were significantly heavier than pups at land breeding sites.

\begin{tabular}{llc} 
Habitat & Group & $\begin{array}{c}\text { Weaning weight } \\
\text { in } \mathbf{~ k g} \pm \mathbf{S D}(\mathbf{n})\end{array}$ \\
\hline Land & Males & $38.1 \pm 7.5(42)$ \\
& Females & $36.8 \pm 7.8(48)$ \\
Ice & Pooled & $37.4 \pm 7.7(90)$ \\
& Males & $50.1 \pm 8.4(35)$ \\
& Females & $47.2 \pm 7.6(54)$ \\
& Pooled & $48.3 \pm 8.1(89)$
\end{tabular}

\section{RESULTS}

\section{Pup Mass on Ice and at Land Breeding Sites}

No significant differences were found in weights of male and female pups for any of the stage classes when comparing pups from the same habitats. Thus, for pups born on ice there was no significant difference in weight between the sexes for pups in stage classes 3.5 and 4.0 combined $(d f=54, t=1.996, p=0.113$, Table 1). Also, at the land breeding sites pup weights were similar for the two sexes in the combined stage classes 3.5 and $4.0(\mathrm{df}=87, \mathrm{t}=1.99, \mathrm{p}=0.44)$. Consequently, in the following analyses we pooled data for the sexes and only compare pup weights as such on ice and at land breeding sites.

Pups in classes younger than stage 3.0 showed similar weights both on land and on ice, which also suggest similar weights at birth. However, for stage classes 3.5 and 4.0 combined, pups born on ice were significantly heavier (48.3 \pm $8.1 \mathrm{~kg})$ than land born pups $(37.4 \pm 7.8 \mathrm{~kg}, \mathrm{df}=176, \mathrm{t}=7.997, \mathrm{p}$ $<0.0001$ ) (Table 1). This significant difference remains also when comparing stage 4 pups (about 18 days old) only ( $d f=63$, $\mathrm{t}=1.998, \mathrm{p}<0.0001$ ) or any other combination of stage classes 3.5 and 4.

\section{Pup Density, Mortality, and Morbidity on Ice}

Group sizes ranged from single mother-pup pairs up to 23 pairs, whereas mean group size was 7.4 (SD 21.0). The frequency distribution of the groups appeared to be closely described $\left(\mathrm{R}^{2}\right.$ $=0.92$ ) by the power function $\mathrm{y}=110 \times \mathrm{x}^{-2.00}$, where $\mathrm{y}$ is the number of groups and $x$ the number of seals in each of the groups.

Using the mean value of each distance category, we plotted mean distance to the closest neighbor, $\mathrm{x}$, against the number of seals in the categories, $\mathrm{y}$, and find that this distribution is also closely described $\left(\mathrm{R}^{2}=0.92\right)$ by a power function $\mathrm{y}=2285.1 \times$ $\mathrm{x}^{-0.945}$ (Fig. 2). Consequently, $45.6 \%$ of the pups were found in the densest category $0-50 \mathrm{~m}$, where the mean pup density was estimated at 0.20 pups $100 \mathrm{~m}^{-2}$ (Fig. 2).

The mean mortality rate among 614 ice-born pups was $1.5 \%$ (Table 2), whereas the morbidity rate is indicated to be very low as none of the investigated 605 live pups showed external signs of infections or septic lesions, although occasional pups $(<1 \%)$ had minor scars.

In the sample of pups born on ice in Estonia in 2001 ( $\mathrm{n}=$ 200), only four (2\%) were found dead, of which two were stillborn, and two had died of other reasons.

\section{Pup Density, Mortality, and Morbidity on Land}

Pup densities at Innarahu varied between 0.46 and 5.2 pups 100 $\mathrm{m}^{-2}$ during the study period 1991-2000, and mortality rate was positively correlated to density $(\mathrm{df}=10, \mathrm{~F}=18.85, \mathrm{p}=0.002$, Fig. 3). Of the 2952 pups estimated to have been born totally at

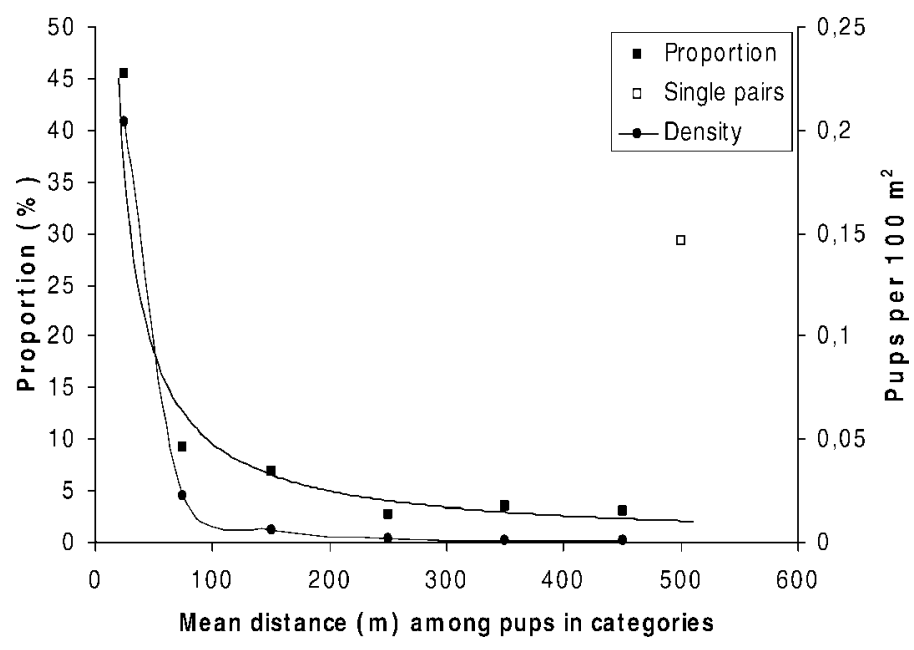

Figure 2. Mean distance to closest neighboring pup on ice. Proportions (squares), and densities (filled circles, given as numbers $100 \mathrm{~m}^{-2}$ ) of mother-pup pairs for seven spatial categories, where mean pup distances varied between 1-50 m, 51-100 m, 101$200 \mathrm{~m}, 201-300 \mathrm{~m}, 301-400 \mathrm{~m}, 401-500 \mathrm{~m}$, and >500 m. The last category (open square) would represent mother-pup pairs without association. Proportions of pups in different categories fitted to $y=$ $748 x^{-0.946}, R^{2}=0.92$. Numbers of pups $=338$.

the two land breeding sites, $622(21.1 \%)$ were registered dead (Table 2), which is an order of magnitude greater than in the ice habitat. At the land breeding sites, pups showed traumatic injuries, mainly in the form of bleeding wounds in the head-neck region and infected wounds on hind flippers. At Innarahu, infected eyes and discharge from nostrils were recorded among $21 \%$ of pups (46 out of 216 observed) in 1992, whereas less than $5 \%$ of pups at Allirahu showed similar symptoms in the same year. Starvation was a common condition among dead pups. Forty-two of the $46(90 \%)$ examined dead pups at Innarahu in 1997, had died within the first week of their life, and the mean weight of 29 dead pups was $10.8 \mathrm{~kg}$.

\begin{tabular}{|c|c|c|c|c|}
\hline Area/year & $\begin{array}{c}\text { No. of } \\
\text { pups }\end{array}$ & $\begin{array}{l}\text { No. } \\
\text { dead }\end{array}$ & $\begin{array}{c}\text { Prop. } \\
\text { dead (\%) }\end{array}$ & $\begin{array}{l}\text { Ice cover } \\
\mathbf{k m}^{2} \times 10^{3}\end{array}$ \\
\hline \multicolumn{5}{|l|}{ Ice } \\
\hline 1990 & 77 & 0 & 0.0 & \\
\hline 1991 & 82 & 1 & 1.2 & \\
\hline 1992 & 157 & 4 & 2.5 & \\
\hline 1993 & 98 & 0 & 0.0 & \\
\hline 2001 & 200 & 4 & 2.0 & \\
\hline Total & 614 & 9 & 1.5 & \\
\hline \multicolumn{5}{|l|}{ Allirahu } \\
\hline 1991 & 21 & 1 & 4.8 & 122 \\
\hline 1992 & 377 & 119 & 31.6 & 66 \\
\hline 1993 & 155 & 4 & 2.6 & 70 \\
\hline 1995 & 175 & 50 & 28.6 & 68 \\
\hline 1997 & 109 & 2 & 1.8 & 128 \\
\hline 1998 & 181 & 22 & 12.2 & 129 \\
\hline 2000 & 488 & 133 & 27.3 & 95 \\
\hline Total & 1506 & 331 & 22.0 & \\
\hline \multicolumn{5}{|l|}{ Innarahu } \\
\hline 1991 & 41 & 3 & 7.3 & \\
\hline 1992 & 328 & 72 & 22.0 & \\
\hline 1993 & 141 & 15 & 10.6 & \\
\hline 1995 & 188 & 23 & 12.2 & \\
\hline 1997 & 238 & 47 & 19.8 & \\
\hline 1998 & 181 & 46 & 25.4 & \\
\hline 1999 & 26 & 0 & 0.0 & \\
\hline 2000 & 303 & 85 & 28.1 & \\
\hline Total & 1446 & 291 & 20.1 & \\
\hline Grand total land & 2952 & 622 & 21.1 & \\
\hline
\end{tabular}




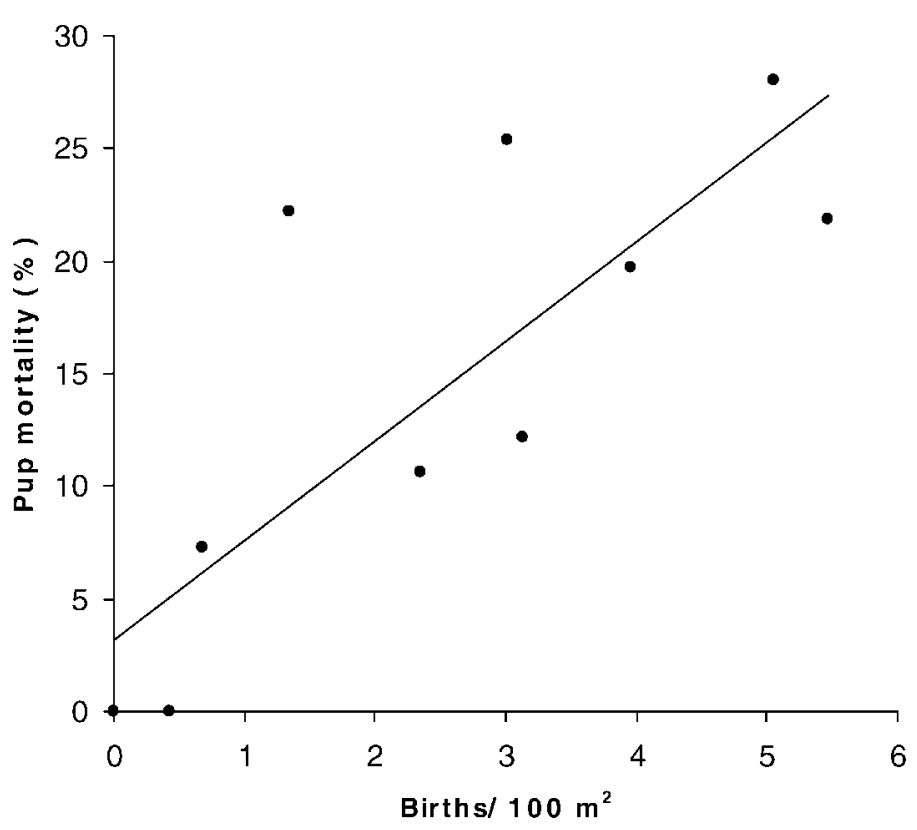

Figure 3. Pup mortality rates and birth densities were positively correlated (analysis of variance: $F=18.8, p=0.002$ ) at Innarahu during the study period.

The number of pups born on land at both study sites Allirahu $(\mathrm{df}=10, \mathrm{~F}=6.26, \mathrm{p}=0.03)$ and Innarahu $(\mathrm{df}=10, \mathrm{~F}=$ $10.06, p=0.01$ ) showed significantly negative correlations with the annual maximum ice coverage of the Baltic Sea (Fig. 4).

\section{DISCUSSION}

We defined female fitness as number of offspring in the far future according to McNamara and Houston (6), which in practice has two major components: life-time net reproductive rate $\left(R_{0}\right)$ measured as number of offspring (7), and the quality of offspring (6). We compared these aspects of female fitness of grey seals in two types of breeding habitats and found that indices of life-time net reproductive rate (pup survival) and the quality of offspring (pup weaning weight) were higher on ice as compared with land. We also showed that females chose the ice for breeding when both land and ice habitats were available. We shall discuss and evaluate these findings in the following.

\section{Reproductive Effort}

The reproductive effort is a central technical term in life history theory. It is either measured as survival cost, where reproducing females could suffer higher mortality, or a potential fecundity cost where energy used for present reproduction could lower body growth, resulting in decreased future reproductive output $(6,15)$. However, in most studies confounding factors make it difficult to obtain detailed information on energy allocation and the cost in the form of survival. One way to overcome the problem of measuring energy allocation would be to use model organisms where the annual energetic allocation to reproduction is fixed from the attainment of sexual maturity and until death. Thus, in species that reproduce repeatedly and where the annual reproductive allocation is delimited to a certain amount of energy, two possibilities emerge: either to reproduce or not. Consequently, such species can, at reproductive size, allocate available energy to either reproduction or growth. Further, there will be no other possibilities to affect the $\mathrm{R}_{0}$ except from varying the age at first parturition (AFP) and the survival rate.

One interesting feature of such a model organism is that the $\mathrm{R}_{0}$ will be constant if the trade-off between present fecundity and longevity is optimized, i.e., under these circumstances a
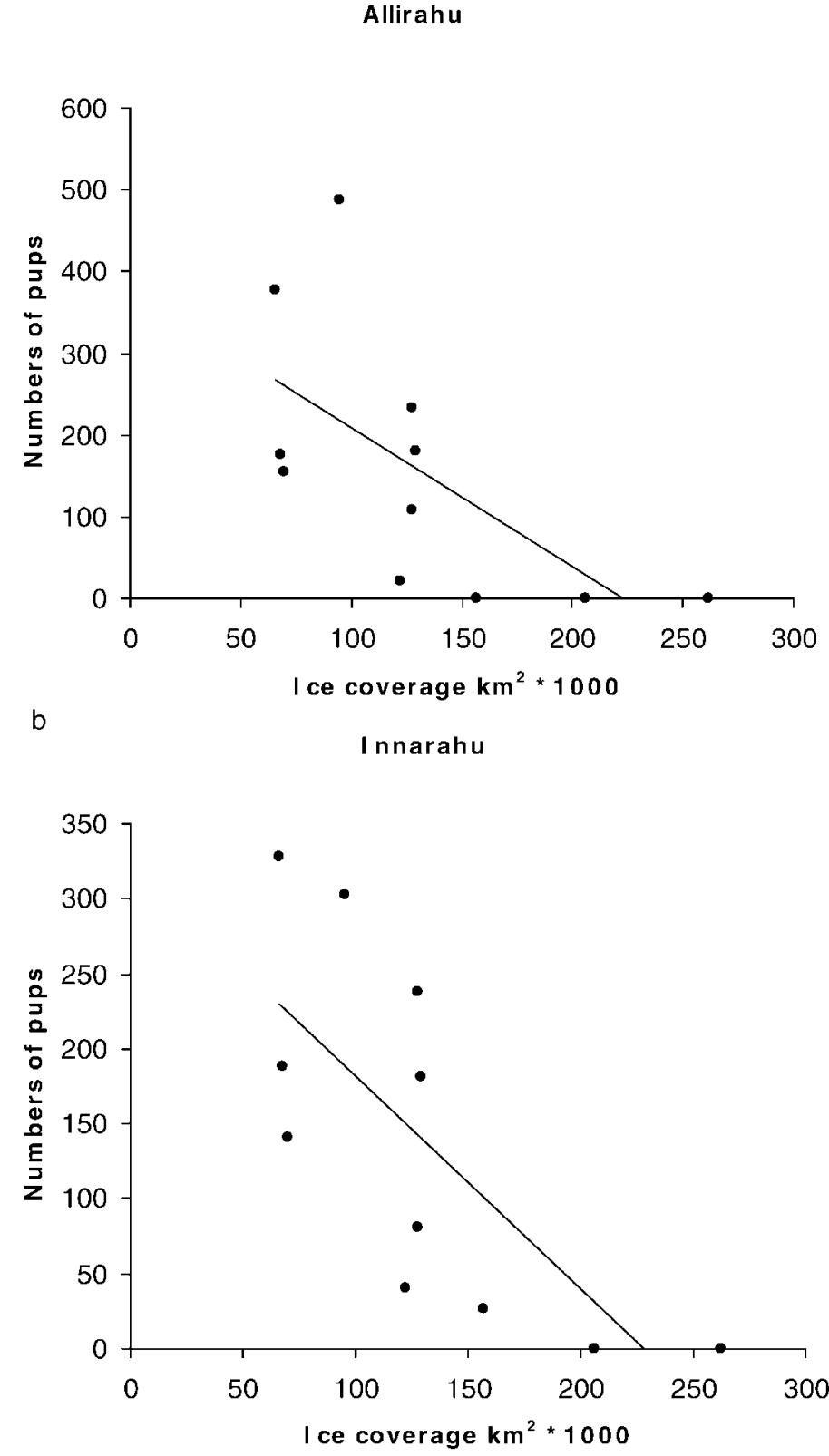

Figure 4. Birth densities at land breeding sites and the extent of ice cover in the Baltic through 1991-2001. Negative correlations were shown both at Allirahu (analysis of variance: $F=6.26, p=0.03$ ) and Innarahu (analysis of variance: $F=10.05, p=0.01$ ).

changes in AFP will not affect $\mathrm{R}_{0}$, whereas the number of offspring in the far future will increase with decreasing AFP as a consequence of decreasing generation time. Hence, the use of $R_{0}$ as a measure of fitness as suggested in theoretical and empirical studies (16) would be futile in cases like this. The optimal strategy for the organism outlined here is to reproduce as early as possible, thereby maximizing the numbers of offspring in the far future. However, a force in the opposite direction is given by the fact that early reproduction is indicated to reduce survival rates or the quality of offspring $(10,17)$.

Grey seals possess most features of this model organism. They are long-lived animals that at the most produce one offspring each year, i.e., the energetic investment in the offspring is basically similar at each occasion. Furthermore, grey seals, as many other true seals, are capital breeders that rely on stored energy for lactation $(18,19)$, when average females use $85 \%$ of their reserves (20). The nursing period is relatively short (2-3 weeks), as compared with the long foraging 
period when the energy is accumulated in form of a subcutaneous blubber layer (21). Recoveries of marked individuals (10) and satellite telemetry (22) indicate a wide dispersal of individuals in the entire Baltic Sea during the icefree period. Thus, feeding conditions and feeding areas during the energy accumulation period can be considered similar in females giving birth in different habitat types. Consequently, the reproductive effort of females can be regarded as similar among ice- and land-breeding females, and the fitness of a female will be directly linked to pup survival and quality.

\section{Influence of Habitat on Condition and Survival of Pups}

Factors affecting breeding success in pinnipeds are found to be dependent on topography (23) and birth density (24). Ice can be regarded as an unlimited breeding area, whereas breeding grounds on land are limited to suitable fractions of islands (23). Births on ice are dispersed across wide areas where interactions among mother-pup pairs are low or nonexisting (25), whereas on land, limited suitable areas in many cases result in dense colonies (26). Ice provides a spectrum of substrata, from small unstable ice floes exposed to wind and wave action to stable fast ice. Baltic grey seals breed predominantly on large stable ice floes (10), but early ice break-up or ice pressure caused by storms are potential dangers to young pups. However, loss of the breeding platform is not fatal to young seals, as they are capable swimmers already at early ages. Mothers assisting their pups to safe grounds have been observed both by Hook and Johnels (10) and during the expeditions of this study. Also, mothers attend their offspring on ice floes or in close proximity even when ice fields drift long distances at high speeds (10). Thus, there is no support for assuming ice instability to be an important cause of pup mortality under severe and normal ice conditions.

The land and ice substrata also differ as sources for infectious agents. The low temperature on ice, which forms annually, will lead to a relatively sterile environment, whereas the ground is more contaminated and has higher risks for infections $(24,26)$. Morbidity rates among ice-born pups are suggested to be very low, as very few dead pups have been found during expeditions on ice (10). Furthermore, apart from small uninfected wounds, probably caused by attacks of large gulls, no signs of infections or septic wounds have been noted.

At land breeding sites the ground can be a primary source of infection (24), while interactions between seals and traffic in a breeding colony increase contact rates among individuals. Virological studies of grey seal pups in 1992 and 1993 (at Innarahu) showed that 14 of 15 sampled (93\%) were infected by Calici virus and that Herpes and an unidentified Morbilli virus were common in sampled pups (B. Westerling and K. Kulonen pers. comm.). None of these viruses were lethal to grey seal pups, but were considered responsible for weakening the general condition and resistance of the immune system.

Also, potential predation and disturbance by birds is likely to differ between the habitats. Low attendance rates of birds in the vicinity of ice-born pups is indicated by the frequent presence of placentas, whereas on land only one placenta was observed during the entire study period. Here, placentas are probably consumed by the numerous gulls soon after delivery. Throughout the breeding season, white tailed eagles (Haliaetus albicilla) are present at land breeding sites, with a maximum observation of eight birds at a time for both study sites. Eagle attacks on grey seal pups invoking a defense reaction of several grey seal females were recorded in both studied land-breeding sites. Thus, high pup concentrations in restricted areas of islands probably increase contact rates between large birds and seals.
Pup morbidity and mortality are closely linked to the type of breeding habitat $(24,26)$, which is supported by the findings of this study. In most cases the primary causes of death remain unknown, but the absence of subcutaneous fat indicated longterm starvation. Pup mortality rates observed on land in this study are similar to major land-breeding colonies at the British Isles, where mortality rates ranged between $10 \%$ and $35 \%(23$, 24, 26).

\section{Quality of Offspring}

The growth of grey seal pups is closely linked to the maternal energetic investment during lactation (20), but as discussed earlier, this allocation is likely to be similar in both studied habitats, because the same females alternate between ice and land breeding. However, two major components contribute to this energy allocation: energy transfer to the pup (23) and energy required by the female for maintenance and activity during the lactation period. The latter component has not been given much attention in earlier studies, but is likely to vary substantially among breeding sites. The highest densities of females are in the proximity of pools (27), and lactating Baltic grey seals frequently spend time in the water (12). This behavioral feature may be linked to thermoregulation, and access to water could therefore reduce the physiological stress of lactating females (27). Furthermore, movements between the pup and the water may be more costly in dense colonies because both the distance to water and interactions with other seals is expected to increase with seal density $(21,27)$. Therefore, energy expenditure of females, measured as weight loss (20, 21), may not be directly linked to mother-pup energy transfer.

Similar energetic effects can be expected in pups since physiological stress and harassment may vary with environmental conditions and density. Therefore, we expect energy transfer efficiency to be higher in areas with favorable environmental conditions and low seal densities. This is corroborated by empirical data from both West and East Atlantic grey seal populations $(21,23,27)$. In areas with low seal densities (Sable Island, Amet Island, and ice) the mean daily weight gain of pups is higher as compared with areas of high seal densities (e.g., North Rona and our land breeding areas). Although initially lighter, ice-born pups in the Baltic attain similar weaning weights as found in Atlantic populations. Pups born on ice in the Baltic were also heavier at weaning as compared with other East Atlantic populations, whereas land-born Baltic pups exhibited the lowest weaning weights. Our results confirm that negative effects on pup growth appear at high densities, but such effects are less explicit when density is low.

There is no evidence that weaning weights differ between land and ice breeding habitats in Canadian seals. However, in the only study (19) where data were collected from both habitats, land breeding conditions (e.g., density) were not specified. Because the reported breeding area was $6600 \mathrm{~m}^{2}$ and the largest sample of pups was 48 , it is possible that the breeding density was too low to affect pup growth. However, a later Canadian study showed that ice-born seals are nursed during a shorter period (15 days) and grow faster although the received energy was the same when compared with studies of land breeders (21).

Our principal finding was that pups born on ice were significantly heavier at weaning as compared with pups born on land (Table 1). We therefore suggest this difference in weaning weights primarily to be a consequence of higher energetic expenditure on land by both pups and females, although the generally poorer health condition at land breeding sites may be a contributory factor. The high weaning weight of pups is correlated to increased chances of survival (28). Consequently, 
it could be expected that females give birth in habitats maximizing their fitness in terms of pup survival and quality. Baltic grey seal females selected ice over land sites when both were available (Fig. 4).

\section{Consequences}

The scenario of retreating ice fields (5) will force a great majority of Baltic grey seal females to breed on land, which will reduce their fitness both in terms of life-time net reproductive rate and pup quality. Major predicted consequences will be a lowered and more variable future mean population growth rate, a combination leading to dramatically enhanced risks for quasiextinction (29). The accepted Helsinki Commission seal recommendation from 2006 identifies three main long-term management principles: natural distribution, natural abundance, and a health status that secures the long-term persistence of Baltic seal species. Remedial actions can only be taken when these long-term management principles are not compromised, which in practise implies that population growth rates of Baltic seal species and populations should be positive until leveling off for natural reasons. The predicted reduced and more variable population growth rate of Baltic grey seals in the future would entail that the time for reaching the first two long-term goals will be substantially extended as compared with the current situation and that the risk for rapid declines will be greatly enhanced.

\section{References and Notes}

1. Lindsay, B. 2005. Thawing out Northern mammals. The Science Quarterly 2, 1-4

2. Derocher, A.E., Lunn, N. J. and Stirling, I. 2004. Polar bears in a warming climate. Int. Comp. Biol. 44, 163-176.

3. Humphries, M.M., Umbanhowar, J. and McCann, K.S. 2004. Bioenergetic prediction of climate change impacts on northern mammals. Int. Comp. Biol. 44, 152-162.

4. Kalliosaari, E. 1996-2000. The Ice Winters 1995-2000. Finnish Ice Service. (http://ice. fmi.fi/winter95 96.html)

Meier, H.E.M., Döscher, R. and Halkka, A. 2004. Simulated distributions of Baltic Seaice in warming climate and consequences for the winter habitat of Baltic ringed seals. Ambio 33, 249-256.

6. McNamara, J.M. and Houston, A.I. 1996. State-dependent life histories. Nature 380 , 215-221.

. Gadgil, M. and Bossert, W.H. 1970. Life historical consequences of natural selection. American Naturalist 104, 1-24.

8. Boskovic, R., Kovacs, K.M., Hammill, M.O. and White, B.N. 1996. Geographic distribution of mitochondrial DNA haplotypes in grey seals (Halichoerus grypus). Can J. Zool. 74, 1787-1796.

9. Harding, K.C. and Härkönen, T. 1999. Development in the Baltic grey seal (Halichoerus grypus) and Ringed seal (Phoca hispida) populations during the 20th century. Ambio 28, 619-627.

10. Hook, O. and Johnels, A.G. 1972. Breeding and distribution of grey seal (Halichoerus grypus Fab.) in the Baltic Sea with observations of other seals in area. Proceedings of the Royal Society of London B 182, 37-58.

1. Steffenson, J. 1976. Livet på Runö. LTs Förlag, Stockholm, 129 pp. (In Swedish).

12. Jüssi, M. 1999. Breeding Habitat Preference and Reproduction Success of Baltic Grey Seal (Halichoerus grypus). Master Thesis, University of Tartu, Institute of Zoology and Hydrobiology, Estonia, 41 pp.

13. Kovacs, K.M. and Lavigne, D.M. 1986. Maternal investment and neonatal growth in phocid seals. J. Anim. Ecol. 55, 1035-1051.

14. Lorentsen, S.H. and Bakke, Ø. 1995. Estimation of grey seal Halichoerus grypus pup production from one or more censuses. In: Whales, Seals, Fish and Man. Blix, A.S. Walløe, L. and Ullatang, Ø. (eds). Elsevier Sci BV, Amsterdam, pp 47-51.

15. Shine, R. and Schwarzkopf, L. 1992. The evolution of reproductive effort in lizards and snakes. Evolution 46, 62-75.

6. Partridge, L and Sibly, R. 1991. Constraints in the evolution of life histories. Phil. Trans. Roy. Soc. Lond. 332, 3-13.

7. Stearns, S.C. and Koella, J.C. 1986. The evolution of phenotypic plasticity in life-history traits: predictions of reaction norms for age and size at maturity. Evolution 40, 893-913.

Bowen, W.D., Oftedal, O.T. and Boness, D.J. 1992. Mass and energy transfer during Bowen, W.D., Oftl lactation in a small phocid, harbour seal (Phoca vinlina). Physiol. Zool. 65, 844-866.

9. Baker, S.R., Barrette, C. and Hammill, M.O. 1995. Mass transfer during lactation of an ice-breeding pinniped, grey seal (Halichoerus grypus) in Nova Scotia, Canada. J. Zool. London 236, 531-542.

20. Anderson, S.S. and Fedak, M.A. 1985. Grey seal males: energetic and behavioural links between size and sexual success. Anim. Behav. 33, 829-838.

21. Haller, M.A., Kovacs, K.M. and Hammill, M.O. 1996. Maternal behaviour and energy investment by grey seals (Halichoerus grypus) breeding on land fast ice. Can. J. Zool. 74 , $1531-1541$.

22. Sjöberg, M. 1999. Behaviour and Movements of the Baltic Grey Seal. Implications for Conservation and Management. Doctoral dissertation, Acta Universitatis Agriculturae Sueciae, $33 \mathrm{pp}$.
23. Pomeroy, P.P., Fedak, M.A., Rothery, P. and Anderson, S. 1999. Consequences of maternal size for reproductive expenditure and pupping success of grey seals at North Rona, Scotland. J. Anim. Ecol. 68, 235-253.

24. Baker, J.R. 1984. Mortality and morbidity in grey seal pups (Halichoerus grypus). Studies on its causes, effects of environment, nature and sources of infectious agents and immunological status of pups. J. Zool. London 203, 23-48.

25. Bedard, C. 1993. The Reproductive Behaviour of Grey Seals (Halichoerus grypus) Breeding on the Seasonal Pack Ice in the Gulf of St. Lawrence, Canada. M.Sci. Thesis, Breeding on the Seasonal Pack Ice in the Gulf of
University of Waterloo, Ontario, Canada. $57 \mathrm{pp}$.

26. Baker, J.R. and Baker, R. 1988. Effects of environment on grey seal (Halichoerus grypus) pup mortality. Studies on isle of May. J. Zool. London 216, 529-537.

27. Redman, P., Pomeroy, P.P. and Twiss, S.D. 2001. Grey seal maternal attendance patterns are affected by water availability on North Rona, Scotland. Can. J. Zool. 79 , 1073-1079.

28. Hall, A.J., McConnell, B.J. and Barker, R.J. 2001. Factors affecting first year survival in grey seals and their implications for life history strategy. J. Anim. Ecol. 70, 138-149.

29. Harding, K.C., Härkönen, T., Helander, B. and Karlsson, O. 2002. Status of Baltic grey seals: population assessment and risk analysis. NAMMCO Scientific Publications 6, 33 56.

30. Acknowledgments: We are grateful to Ian Boyd, Paddy Pomeroy, and Gordon Waring for valuable comments, and thank Bjørn Munro Jensen for providing detailed data on stage classes of grey seal pups. The study was financially and technically supported by WWF-Finland, the Finnish Institute of Game and Fisheries Research in 1990-1993, and the Estonian Ministry of Environment in 1995-1998. Field expeditions were carried out by joint expeditions arranged by WWF-Finland and the Estonian Fund for Nature. T. H. was financed by the Swedish Environmental Protection Agency. The handling of seals was carried out according to permits issued by Estonian and Finnish authorities.

31. First submitted 15 May 2007. Accepted for publication 5 July 2007.

Mart Jüssi, MSci, is currently a member of the Estonian Parliament for the Green party. He started modern seal research in Estonia together with his brother Ivar and is engaged in several projects including EU-Life and the Caspian seal project, focused on research and conservation of biodiversity. He has worked for prolonged periods at the Finnish Game and Fisheries Research Institute and the Sea Mammal Research Institute in the UK. His address: Estonian Fund for Nature, PO Box 245, Tartu, Estonia EE 50002.

E-mail: mart.jussi@gmail.com

Tero Härkönen is associate professor and has a research position at the Swedish Museum of Natural History. He is in charge of an environmental monitoring program in Sweden encompassing harbor seals and ringed seals. He has been, or is running projects on marine mammals in Greenland, the Antarctic, and the Caspian Sea, and is currently engaged in establishing conservation and management plans for all Baltic seal species through work in the HELCOM and the ICES. His address: Swedish Museum of Natural History, Box 50007, S10405 Stockholm Sweden.

E-mail: tero.harkonen@nrm.se

Eero Helle, PhD, is the General Director of the Finnish Game and Fisheries Research Institute, but started his professional life as a seal scientist. His pioneer work included the disclosure of detrimental effects of PCB on the reproduction of Baltic ringed seals and development of methods for aerial censuses of ice seals. He has been in charge of a vast number of projects studying various game species. His address: Finnish Game and Fisheries Research Institute, PO Box 2, FI 00791 Helsinki, Finland.

E-mail: Eero.Helle@ rktl.fi

Ivar Jüssi, MSci, has worked alongside his brother Mart with seal research for many years and is responsible for establishing conservation and management plans for seals in Estonia. $\mathrm{He}$ is engaged in EU-Life projects and the Caspian seal project focusing on biodiversity and conservation of marine mammals. $\mathrm{He}$ also contributes to the HELCOM and ICES working groups on marine mammals. His address: State Nature Conservation Centre, Narva 7 A Tallinn, 15172, Estonia.

E-mail: Ivar.Jussi@gmail.com 